István Posgay, Gábor Regós, Diána Horváth, Dániel Molnár

\title{
On the Economic Impacts of the Coronavirus
}

\section{Summary}

The year 2020 saw a new economic crisis shake the world more deeply than the 2008 one. This downturn differs from the previous ones: instead of the internal patterns of the individual economies, the predominant factors to determine the pace of fall are the constraints related to the pandemic. Although most of the currently used anti-crisis tools had already developed as a result of the 2008 crisis, new elements include increased harmonisation between the monetary and fiscal policies and the speed of their application. The various economies will recover from the economic low point fundamentally by economic factors, supported by fiscal and monetary policy instruments, but pandemic obstacles may emerge and compel them to halt. Another problem is that it may take several years to achieve pre-crisis output levels. This is due to population ageing, the cascaded deployment of the anti-crisis tools, the future compulsion to reduce indebtedness, the side-effects of the applied anti-crisis remedies, the time required by the reorganisation of global supply chains, slowdown in China's growth, the expected slow recovery of the US economy and the too high propensity to save on behalf of the consumers of certain European countries.

Journal of Economic Literature (JEL) codes: E52, E62. H12

Keywords: economic crisis, Coronavirus, crisis management, monetary policy, fiscal policy

István Posgay, Research Associate, Századvég Economic Research Institute (posgay@szazadveg.hu); GÁBor REGốs PhD, Head of Macroeconomic Section, Századvég Economic Research Institute (regos@szazadveg.hu); Diána Horváth, Macroeconomic Analyst, Századvég Economic Research Institute, and PhD student, Corvinus University of Budapest (horvath.dia@szazadveg.hu); DÁnIEL Molnár, Macroeconomic Analyst, Századvég Economic Research Institute and PhD student, Corvinus University of Budapest (molnar.daniel@szazadveg.hu). 
Istuán Posgay, Gábor Regós, Diána Horváth, Dániel Molnár: On the Economic Impacts...

\section{INTRODUCTION}

The worldwide spread of the coronavirus has significantly reshaped the lives of most countries in the first half of this year. Measures taken to curb the pandemic have profoundly affected not only life and societies but also the functioning of the economies and the world economy as a whole. This paper describes these economic effects, the nature of the crisis, the downturn caused by the pandemic, and the possible methods of recovery. The current crisis may well exceed the 2008-2009 recession, and the question arises as to how long and at what pace GDP will reach pre-crisis levels, and what factors will determine it. The aim of this paper is to give an overview of the characteristics of the crisis and of the measures taken so far, mainly with an international focus, although responses to the crisis will be more or less country-specific. Not only because the economies of the individual countries show significant differences, but also because they were in different macroeconomic situations when they were hit by the crisis, and the combination of fiscal and monetary policy measures was also unique. In addition, the epidemiological measures taken and the diagrams showing the number of people affected by the pandemic also differ, and as a result, the effects of the pandemic on the economy, including all measures and social reactions, are likely to be different.

\section{ON EPIDEMIOLOGICAL MEASURES AND THEIR ECONOMIC IMPACT}

A pandemic can be divided into stages in several ways: according to the number of people involved in the pandemic, such as those infected or hospitalised, or the epidemiological measures taken. Without giving a detailed analysis of the interrelationship between the two, it is worth noting that the introduction of restrictions was also influenced by a number of political, economic, and psychological factors, including the subjective ability of a country's political leadership to assess the situation.

The beginning of the pandemic was mainly accompanied by a few local restrictive measures, but no really strict general epidemiological restriction was imposed. The spread could not be stopped, at most only slowed down. The economic effects mainly included by the impact of the pandemic risk on consumer behaviour and were mainly manifest in the fact that demand for tourism, hospitality, event organisation, or transport services decreased due to the caution taken by individuals.

In the next phase, the risk of mass illnesses emerged, and so epidemiological measures were also aimed at preventing its unfolding. However, the restrictions imposed at that time already had serious economic effects and led to a decline in the performance of economies: limited demand triggered downward cumulative economic processes. Restrictive measures resulted in shrinking production, and in some cases downtimes, supply difficulties, and damage to global value chains.

In addition to the direct economic effects of restrictions, the psychological element is also important. An unprecedented social and economic situation emerged: the end of the pandemic is unpredictable, and this has created uncertainty for con- 
Civic Review · Vol. 16, Special Issue, 2020

sumers and businesses, thus damaging both demand and supply. Consumption and demand for investment faltered due to deterioration in business confidence and to barriers to supply, both for producers and consumers. The former generated temporary overpurchase, in the case of "pandemic goods", such as disinfectants, masks, hygiene products, durable foods, medicines, etc., a temporary overdemand appeared, causing a disruption in supply. Production disruptions and weak economic activity challenged the stability of corporate finances, productivity growth stalled, and the missed revenues threatened companies with insolvency.

In some countries, such as Italy or Spain, which entered a phase of mass illness in the first wave, non-basic economic activities also came to a halt, predicting a greater economic downturn compared to other countries. It soon became clear that in the short run, the correlation between increasing anti-pandemic measures and declining economic activity was inevitable. It seems that this problem can only be solved by the appearance of the vaccine.

In the period of tightening up anti-pandemic measures, economies are experiencing downward cumulative processes, resources are depleting, the financial system is shaken, capital is shrinking, labour is being eliminated, and global value chains are being damaged. Once anti-pandemic measures come to a halt, there is a chance that the economy may stabilise in a short time. However, without further intervention, this will merely "anchor" economic activity at a level characterising the end of the downturn. The only way up from there - still assuming there is no other intervention, such as state intervention - is to relax the epidemiological measures. This, in turn, may increase the risk of a repeated outbreak of the pandemic, increase individual health exposure, and broad social consensus and sufficient political leadership is essential for relaxation.

\section{CHARACTERISTICS OF THE CORONAVIRUS CRISIS}

In relation to the economic crisis generated by the coronavirus pandemic, soon opinions wee voiced that this recession is different from the previous ones considered "customary" (Tan, 2020), which raised the question of the need for a different management. Not only is aggregate demand insufficient to maintain the output level, but supply and individual psychological shocks also hit the economic agents. The human factor of production is partially "hindered": the minority, i.e. those infected, because of their health condition or because of being a potential source of health hazards, and also the majority, due to the need to protect health at a personal and social level.

The current crisis is also unique in terms of its outbreak: because the sectors that were shocked by social distancing were its main starting points. The areas first and the hardest hit by the crisis were not "selected" by economic factors, as happened with the financial sector in 2008, but by non-economic measures.

However, a decrease in the output sooner or later leads to a decrease in the aggregate demand. And so it did. The rate of GDP decline in Q2 2020 was 13.9 per cent on an annual basis for the EU and 14.7 per cent for the euro area. During the 
István Posgay, Gábor Regós, Diána Horváth, Dániel Molnár: On the Economic Impacts...

2008-2009 crisis, the fastest decline was recorded in Q1 2009, at 5.5 and 5.6 per cent, respectively. In the U.S., the aforementioned figure fell 9 per cent, which is also 2.25 times the 2009 low point.

The pandemic has clearly caused a very rapid restructuring in demand: for some services - offered by tourism, hospitality and event organisation - demand has essentially disappeared. Although, temporarily, some products - such as durable foods, detergents, medicines - demand increased sharply due to early purchases and a change in the consumption patterns, this was basically due to psychological and "perceived" coercive factors. Thus, these processes do not reflect an increase in the aggregate demand, but rather conceal a decrease, as incomes are already declining, and so they can be understood as consumers' "emergency reaction".

Domestic and international economic circulation has also slowed significantly. Under such economic conditions, if entities are to avoid financial difficulties, protecting their liquidity is essential, which implies cuts in non-critical expenditures, such as investment. The demand and supply shock is also exacerbated by the extra uncertainty surrounding expectations about the health outlooks. Another specific element is the time factor. The drastic speed of decline in the active factors of production is also a unique feature of this crisis, as it has not been determined by the economy's rhythm in contrast to previous crises, but by the extent and speed of "shutdown measures". As a result, the economic fall is sudden and simultaneous to the output level allowed by the epidemiological measures in force. Consequently, due to the different contents and extents of anti-pandemic measures, the rate of decline also varies significantly in the various countries.

In terms of output, there is a perception that economies have temporarily lost the labour and capital that could not be used under the given epidemiological regulations. Fortunately, this was not the case, which is why many thought that the rebound after the pandemic may be as rapid as the fall had been. However, the situation is not that simple. Aggregate labour and capital stocks may also have been damaged during downtime, and some businesses cannot survive this period. An important question is how long it takes for each economy to reach the pre-pandemic output level. The above is a description of the economic downturn caused by epidemiological measures as a "free fall" without external intervention, but fortunately, this downturn has not been a free fall - the governments have stretched the safety net as much as they could.

\section{LESSONS LEARNED FROM THE ADOPTED MEASURES}

\section{The toolbox of anti-crisis measures}

Without going into details on the measures taken by governments and central banks in each country to help recovery ${ }^{1}$, there is a high degree of overlap in the anti-crisis measures, which is, of course, understandable. The following table summarizes the typical measures. 
Civic Review · Vol. 16, Special Issue, 2020

Table 1: Fiscal and monetary policy measures used during the coronavirus pandemic

\begin{tabular}{|c|c|}
\hline Fiscal policy measures & Monetary policy measures \\
\hline Direct grant scheme & Government bond purchases \\
\hline Tax exemption, tax deferral & Purchase of listed securities \\
\hline Contribution exemption or deferral & Corporate bond purchase scheme \\
\hline Credit guarantee & Overdraft to government \\
\hline Interest subsidy & $\begin{array}{l}\text { Liquidity-providing, low-interest bank loan } \\
\text { programme }\end{array}$ \\
\hline Export credit support & Corporate loan scheme to boost investment \\
\hline Export credit insurance & $\begin{array}{l}\text { Central bank plan for the partial redemption } \\
\text { of corporate loans by commercial banks }\end{array}$ \\
\hline Investment support & Mortgage bond purchase scheme \\
\hline Capital Assistance Plan, capital injection & Entrepreneurial quick loan scheme \\
\hline Employment aid scheme (Kurzarbeit) & Facilitation of capital formation \\
\hline Helicopter money & Interest rate cut \\
\hline $\begin{array}{l}\text { Sector-specific support - health, tourism, } \\
\text { and other areas }\end{array}$ & \\
\hline Municipal support & \\
\hline Leasing cost support (freight transport) & \\
\hline $\begin{array}{l}\text { Increasing unemployment benefits, } \\
\text { extending entitlement }\end{array}$ & \\
\hline $\begin{array}{l}\text { Discounted loss write-down (businesses can } \\
\text { carry their deferred negative tax base with } \\
\text { them to write it down in their next positive } \\
\text { tax year) }\end{array}$ & \\
\hline $\begin{array}{l}\text { Childcare allowance for epidemiological } \\
\text { reasons }\end{array}$ & \\
\hline $\begin{array}{l}\text { Cash compensation for those not entitled } \\
\text { to social security }\end{array}$ & \\
\hline Increased childcare allowance & \\
\hline State loan repayment moratorium & \\
\hline $\begin{array}{l}\text { Mortgage Purchase Program } \\
\text { (through a state mortgage institution) }\end{array}$ & \\
\hline
\end{tabular}

Source: Author's own elaboration

For the time being, it may be said that most of the elements in the toolbox were established as a result of the 2008 crisis, and only two new aspects have emerged. On the one hand, specific elements have been adopted due to the pandemic: in almost all countries, priority support has been given to healthcare and to sectors severely affected by the crisis (tourism, hospitality, hotel industry, transport, etc.); and measures 


\section{István Posgay, Gábor Regós, Diána Horváth, Dániel Molnár: On the Economic Impacts...}

have been taken to compensate for the loss of jobs or income caused by the pandemic. On the other hand, a new element is an increase in the coordination of monetary and fiscal policies, which has not been the case during previous crises. In some countries, central banks have also resorted to the previously taboo instrument of buying government securities, and the idea of central bank government debt financing has also emerged.

The monetary toolbox used by the Bank of Japan (BoJ) is unique and also regarded as a model (Bank of Japan, 2020a; 2020b; 2020c). To stabilise financial markets, the BoJ says it is necessary to stem the rise in risk premiums by buying Exchange Trade Funds (ETFs). In the current economic and financial environment, the primary goal of the central bank is to provide extremely flexible access to liquidity for economic agents. As for the future conduct of monetary policy, the BoJ will continue to buy Japanese government bonds at any rate, as long as it does not reach the designated amount of JPY 80 trillion (about USD 753 billion). In addition, in view of the economic downturn, the central bank strongly supports anti-crisis state economic programmes, in close cooperation with the government. The bank has declared an "aggressive" purchase of ETFs worth about JPY 12 trillion a year (about USD 113 billion), which is twice the amount earmarked for this before the crisis. The BoJ, as a large equity fund buyer, had a total share of approximately USD 256 billion at the end of Q4 2019, representing 80 per cent of the total market. The bank is also doubling the rate of purchases of Japanese real estate funds (J-REIT), with plans to spend JPY 180 billion (about USD 1.7 billion) a year on this. In an effort to prevent the credit markets from freezing, the bank set aside JPY 2 trillion (about USD 19 billion) to buy additional commercial papers and corporate bonds. Experts estimate that the balance sheet of the Bank of Japan could have reached 105 per cent of the GDP by the end of March this year. By comparison, in the case of the Federal Reserve System (FED), this ratio stood at 20 per cent at the end of the last year.

As a result of the measures taken due to the crisis, the assets of the FED also grew rapidly (Federal Reserve System, 2020c; Cox, 2020; Bartash, 2020). Its total balancesheet growth of more than USD 500 billion in a single week is roughly double the highest weekly growth ever measured, which was recorded in October 2008. Purchases of government securities played a large role in the increase in the balancesheet total: net stock growth was about USD 360 billion, and stock levels reached USD 3340 billion in the last week of March 2020. The FED continued to buy assets: it bought government bonds, mortgage-backed securities, and provided large amounts of secured loans to financial corporations. Experts advised, and the FED itself declared, that if the above measures were insufficient to effectively manage the situation, the purchase of assets riskier than corporate bonds may also be on the agenda. This actually took place subsequently, in several stages, partly through the USD 3.6 trillion market for ETFs, and partly through the secondary market, using a USD 750 billion budget set aside for this purpose (Federal Reserve System, 2020b).

Thus, in many countries, government and the central bank started to closely cooperate in a previously unseen way, which allows for complex solutions not been ap- 
Civic Review · Vol. 16, Special Issue, 2020

plied during the usual operation of the economy. If expertly used, these solutions, consider by many as unconventional, may be of great help in combatting the crisis, but at the same time they require thorough theoretical and practical preparation, as unless they are adapted to the national features they become a double-edged sword. Their application should include building confidence in the specific measures in the money market, in the capital market, and in economic actors in general, so that their "deployment" does not cause swings in confidence and in the climate.

\section{Timing the anti-crisis measures}

In general, with regard to economic crises, economic policy measures should aim at slowing downturn. It is important to emphasise that the steps taken in the fall phase should not be confused with the "stimulus" to be given after recession. However, the two cannot completely be separated, as crisis mitigation should focus on the future driving forces. In other words, already the damping phase should focus on future boosting, and the two packages should be considered in combination (and implemented as a single programme in at least two modules).

\section{Anomalies in fiscal policies}

When a country carries out fiscal expansion on its own, increase in domestic demand may feed through to foreign producers: it might worsen the terms of trade through imports or rising prices. Feed-through may be particularly high in small and mediumsized, open economies, and can undermine the effectiveness of their fiscal measures. Theoretically, the international coordination of fiscal expansion should solve this problem. When a country increases its aggregate demand, exchange rate fluctuations are more moderate than in the case of asynchrony between the measures taken by individual countries. In such cases, the country is less likely to suffer significant deterioration in the terms of trade due to strongly different price movements.

It is already clear that government indebtedness will inevitably increase in the next period. This also happened as a result of the previous crisis. As the current crisis has hit some highly indebted states - e.g. Greece, Spain and Italy, the fact that these countries have not been able to stabilise their levels of indebtedness in more than a decade since the last crisis means that they will either be able to achieve some kind of global debt settlement or have a substantial narrowing of their fiscal room for manoeuvre. The problem is at least as acute as it was during the previous crisis, and as the current crisis may be deeper than the previous one, the situation has worsened. If these countries, due to their current high levels of indebtedness, are unable to make further large-scale spending, they will hardly be able to mitigate the downturn and establish recovery. Inevitably, the question will arise for Italy, Spain, Greece, or Portugal on how to deal with the expected surge in debt, which may pose a serious threat to the euro area, to the EU, but to the world economy itself. Many (e.g. Blanchard, Alesina, or Giavazzi) believe that the emergency situation requires extraordinary solutions, 
so maintaining the euro area requires the "special" management of debts incurred during the pandemic in the future (Baldwin and Weder di Mauro, 2020, pp. 49-55). Financing should not be left to the market, the current near-zero interest rates may subsequently rise, mainly as a result of market pricing of risks due to higher debt.

In view of the above, a new EU approach to tackling the crisis and to high debt has emerged. By the end of May 2020, at the initiative of France and Germany, the European Commission had drawn up a proposal for a EUR 750 billion recovery fund (European Commission, 2020d). The concept of the fund also suggests that due to the joint issuance of bonds, a new generation version of the EU ("Next Generation EU") will replace the former cooperation. Two-thirds of the fund is provide as grant and the remainder as loans. The aim is that the usage will be realised in accordance with the priorities set by the Commission (green and digital economy, and increasing competitiveness and resilience), which will promote sustainable and balanced growth after the crisis. All Member States can benefit from it, but as they have been hardest hit by the pandemic and the crisis, their debt does not rise during the restructuring. The proposal, therefore, seeks to stabilise the situation of the most indebted Member States - mainly Italy, Spain, and Greece - in a single settlement, while preventing the recurrence of their indebtedness. A bond to be issued by the Commission, guaranteed by the Member States, would mean that Member States less affected by the coronavirus would indirectly help the - primarily southern - Member States that have been put to disadvantage by the crisis and by high debt levels. Loan repayment is expected in the post-2027 budget cycle(s). All this, of course, is only a proposal for the time being, and serious discussions are expected before finalisation. This may be conceived as an attemptat curbing indebtedness, one of the most threatening internal problems of the EU and the euro area, and at a simultaneous step towards a more coherent fiscal policy.

\section{METHODS OF REGOVERY FROM THE CURRENT CRISIS}

At least four main types of recovery curves (V, U, W, or L) are mentioned in the literature. In addition to the trajectory of recovery, the timing of changes is also important. The most favourable scenario would be a V-shaped GDP trajectory with the low point followed by a bounce of practically the same speed as the fall. The U-shaped trajectory has a prolonged low point, with the bounce occurring later than in the caseof a V-shaped trajectory, but it also takes the economies back to pre-crisis levels. In a $\mathrm{W}$-shaped trajectory, bounces and relapses are expected to follow one another due to several pandemic waves. The most pessimistic expectation is an L-shaped curve for GDP, i.e. the level of economic activity never returning to the pre-crisis trend but only rise to a lower level.

The different versions of theoretically possible recovery scenarios outline economic trajectories depending on how the pandemic is addressed and how effective the fiscal and monetary measures taken will be (e.g. McKinsey \& Company, 2020, p. 20). If the favourable V-curve is followed, the virus is curbed in 2-3 months and then life 
Civic Review · Vol. 16, Special Issue, 2020

is fully restored to pre-epidemiological levels, and policy measures prevent structural damage to the economy. In this case, a country's economy can quickly return to its pre-pandemic growth trajectory.

In the case of a U-curve recovery, successful epidemiological measures, economic protection and stimulus are only partially effective, and thus the economy returns to pre-crisis output levels at a slower pace. In an extreme case, the pandemic is eliminated, but the policy measures are unable to prevent lasting damage to the economic actors, and a debt crisis develops through corporate bankruptcies, which also puts the banking sector in a difficult position. This would be a variation of the L-curve. Output levels in this version are expected to remain permanently below pre-pandemic levels after the recovery.

In a less successful epidemiological case, after the initial, effective epidemiological measures, the virus cannot be completely eliminated, and certain restrictions need to be maintained for a longer time in order to avoid future emerging pandemic risks. Then, in the case of effective government measures, a version of a U-shaped trajectory is worked out, as it is only possible to resume production after several months, but this happens in a quick bounce, so that output can return to pre-pandemic trends over time. This epidemiological trend, combined with less effective public economic measures, would result in a slow recovery, and the economy's output level may approach pre-pandemic levels but not be able to reach them in the short term (L-curve).

In addition to the theoretical methods discussed above, of course, many epidemiological trajectories are possible, if only because each country's measures are unique, and everywhere there is a number of local peculiarities characterising the attitude of the population, which in turn, affects the evolution of the epidemiological situation. However, epidemiological constraints also affect the state of the economy: they determine the depth of downturn and the sectors most exposed to it. In addition to the content, the effects of government measures also depend on timing. A package may have a different effect at the time of the outbreak and in the period after the lifting of epidemiological restrictions. In other words, even under the most optimistic epidemiological scenario, the economic trajectory will be different in the various countries because, due to different epidemiological measures and to the behaviour of the population, the output will "freeze" at different levels and structures. It is also important to clarify that the rate of fall does not predestine a similarly rapid rebound. Instead of a regular V shape, the two stalks of the curve of GDP will certainly be at different angles: the first stalk will be steeper and the second will be flatter. This is unavoidable because the pace of fall is not determined by the laws of the adverse cumulative processes determined by the internal characteristics of economies, but by exogenous elements, mainly epidemiological constraints. During the post-crisis upward cycle, economies move in a manner determined by economic factors, and experience from post-crisis booms has shown that they are unable to produce growth in the pace of the fall, as we have seen after the 2008 crisis (Posgay et al., 2019)

In general, an economic downturn during a crisis does not guarantee rebound at a similar pace, as by that time, the economy has undergone significant changes. 
This is especially true in the case of this crisis, as the restrictive measures have cut off factors of production by physically limiting their interconnectivity. In addition to the supply shock, a demand shock appeared almost simultaneously, through an increasingly significant drop in demand. under such conditions, the output can only grow if its level is not determined by regulatory limits, but by economic - mainly demandrelated - constraints, so that the output can reach the maximum level determined by the epidemiological restrictions.

However, the above is also true in the downward slope: a given level of output determined by restrictions is in vain if the current level of demand does not make it available or sustainable. In this case, in the absence of external assistance, such as state aid, the output starts to fall, according to the classic negative cumulative process rules of a crisis, and only stops when it has reached the level determined by demand. In this partially "hibernated" state of the economy, firms map their supply and demand relationships, constraints, redesign revenues and expenditures, developments, and all other factors that may be essential to survival in the short term. The question rightly arises how flexible this reduced-level system is, how it can adapt to another shock that might come.

Businesses are likely to adapt quickly to the new situation. With levels of epidemiological constraints unchanged, time is an important factor as the longer the restrictions are in place, the greater the chance of serious damage to the economy. The timing of government action is vital. Reduced-income businesses need a source of liquidity to survive, while households that have lost income need revenue. To cushion downturn, businesses need help in preventing damage that requires significant downsizing or results in bankruptcy. State aid granted to stabilise employment can also slow reduction in household consumption. It is expedient to schedule measures for cutting the financial burdens of companies (taxes and contributions), to maintaining liquidity, and to protect jobs during the downward and in the stagnation phases. Particular care should be taken in the case of direct measures taken to stabilise household incomes. This tool may have a more limited effect in the current case than in "usual" demand-driven recessions if it is used for supply-limited products and services. In the event of a supply constraint, additional demand results in price increase. While this increases the nominal income of the entrepreneurs concerned, it does not increase the real economic performance or the real wealth of households. The same measure may have a greater incentive after lifting the epidemiological restrictions, when companies are able to respond to the excess demand by increasing production.

It has become clear that the development and application of government measures may also be perceived as a learning process. It is usually typical - see, for example, Germany, the U.S., Japan, and also Hungary - that economic support measures have been taken in several stages. However, time definitely works against a rapid rebound: if governments want to avoid "re-tightening", after an easing it is reasonable to check whether or not the number of new cases increase to such an extent that the pandemic returns. A possible "re-tightening" would cause significant social, 
Civic Review · Vol. 16, Special Issue, 2020

political and economic damage, and in terms of economic impact, a new tightening would lead to a repeated downturn. This is not only a problem due to declining output levels and demand, as it may repeatedly cut some of the domestic and international production and supply chains that had already been partially rebuilt after the previous downturn, and it might lead to a new structural disruption of the output structure. In this case, the question arises whether micro-economic and macro-economic rescue packages should be repeatedly used, as the effects of any previous packages might partially or even completely be eliminated by new epidemiological restrictions.

Meanwhile, rise in the output requires increase in demand, otherwise companies are unable to take full advantage of the opportunities offered by the elimination of capacity constraints. In this period, businesses and the economic policy will also face a similar "learning process" they undergo during stagnation period immediately before and after the low point. This, however, requires adaptation to completely different economic conditions, as the micro-economic and macro-economic environments already differ from what they were before the crisis, during downturn, or at the time of the low point stagnation. From the perspective of growth, the level of an economy before the pandemic has no primary relevance, it is rather the volume and efficiency of the specific combination of the surviving, refurbished and newly built production factors that matter. Large-scale public capital expenditure projects and investment support programmes for the private sector, scheduled for the time of lifting of epidemiological restrictions, may provide a basis for recovery. It is advisable to supplement them with state programmes in support of corporate and public training courses.

Obviously, not only the timing and content of government measures are important, but also their perception by the public to steer expectations to the positive range.

\section{Conclusions}

In terms of the expected outcome of the crisis, it has been demonstrated that a slower and more gradual economic upturn is expected than downturn was, and thus it may take a longer time to reach pre-crisis output levels. Without claiming to be exhaustive, below is a description of the factors that may influence slowdown in recovery, divided into two groups: exogenous and endogenous factors.

Exogenous factors

Epidemiological restrictions

The downturn that has caused the crisis is not due to endogenous economic reasons, but to epidemiological constraints that cut off a significant number of production factors. These measures determined the main sectors that drove downturn. The speed of recovery is determined by the extent and pace of the lifting of epidemiological restric- 
tions and the economic growth opportunities given by them. Thus, there has been a quasi "free fall" downwards, and the economy will be "back on its feet" - supported by fiscal and monetary policy instruments -, but there may also be epidemiological obstacles forcing several halts. These alone make it inevitable that the pace of recovery will be slower than the downturn was.

Thus, in contrast to previous crises, epidemiological factors appear in both downward and upward movements as external conditions which may impose limits on growth.

\section{Rising political tensions, China's controversial situation}

Budget expenditures, which increased during the crisis, should be curbed after the crisis, and the deficit should be reduced. Such actions are taken to the detriment of some participants, who express their dissatisfaction and may further enhance social tensions. The geopolitical tensions seen before the crisis have been partly exacerbated by the pandemic, and so at times the political and economic tensions between the US and China intensify, and do not seem to be over.

\section{Demographic characteristics}

In developed countries population aging has become a prevailing factor, but this phenomenon is also becoming more pronounced in emerging economies (Fitch Solutions, 2020). Aging counteracts productivity increase on a social level, as the ratio of the working-age and employed population decreases while that of the economically inactive increases. The increasing number of pensioners and their increasing pensions need to be financed by a decreasing number of economically active people. This budgetary burden is increasingly apparent in a period of consolidation.

\section{Endogenous factors}

\section{The efficiency of fiscal and monetary interventions}

Naturally, there is no universally ideal fiscal or monetary package to dampen downturn and to help stimulate the economy. There cannot be one because the epidemiological situation and the structure of the economy are different in each country, so the extent and structure of the damage to the economy are necessarily different. However, the design and application of government measures, as a learning process, can be improved. It is therefore realistic to assume that the initial measures will be followed by further adjustments, tol make them more effective. Thus, the anti-crisis "treatment" of economies is not based on a single intervention, but on multiple "dosing" of "medicines" - the fiscal and monetary tools - in different "doses". Thus, the speed of approaching the efficiency typical of an ideal case may result in a relatively slower post-crisis growth. 
Civic Review · Vol. 16, Special Issue, 2020

Need for the reduction of indebtedness in the future

As a result of the 2008 economic crisis and of the ongoing coronavirus crisis, a system of crisis management tools has become the practice, and has led to a swelling of budget deficits and a surge in private debt due to central banks' money printing. Leverage needs to be phased out after the crisis, budgets need to be consolidated and central bank balance sheets need to be downsized so that financial imbalances do not lead to macroeconomic shocks. This, in turn, requires a reduction in budget expenditures and an increase in revenues, which will inevitably slow down growth. The withdrawal of funds from the private sector, which accompanies the downsizing of central bank balance sheets, also works in this direction. Indebtedness had already been high before the crisis broke out both by state level and in the private sector. In some countries, the necessary rebuilding of leverage did not take place even after the previous crisis, but neither did the required financial consolidation in the case of households and many private companies. More resources should therefore be withdrawn from the economy than the amount pumped in to alleviate the current crisis, which is why slower growth is likely in the coming period.

Market side-effects of using extended crisis management tools

Fiscal spending in support of demand and the central banks' "money pump" can have harmful side-effects in addition to short-term positive stimuli by disrupting market balancing mechanisms. These fiscal and monetary measures are intended to dampen natural market selection during the crisis by compensating for lost income and liquidity. This means that beneficiary households, whose members do not currently work but consume, receive additional income. This is provided by the government, in most cases in the form of newly created money, which - if spent by the household and settled by the state through debt repayment - does not, in principle, upset the balance of money and goods and services.

The situation is similar for companies when the state provides the money for wages or investment support. Problems may arise with subsequent effects. If, as a result of the public cash benefit, increase in the wage results from the employee choosing to work instead of using state aid and leisure time, a global wage increase can take place. This, in turn, makes the output more expensive, as the labour of the same quality will become more expensive, making the labour market itself "sticky" and less flexible. The Fed also indicated in late May 2020 (Federal Reserve System, 2020a, p. 1) that an increasing number of employers were concerned that some of their employees would not want to return to work. In addition to health risks, the loss of childcare allowances is a factor, but so is the more favourable unemployment benefits introduced as a result of the crisis. There may also be problems in the longer term due to business support. Cheap money can keep less profitable businesses afloat for longer, and they can drain resources from more competitive businesses, leading to macro-economic productivity losses. Moreover, intervention in credit and equity 
markets can distort price signals, making it difficult for investors to allocate capital efficiently and effectively. The state should therefore carefully consider the criteria of support to enterprises. If the only goal is to retain the workforce, and no other expectation is related to the benefit, then less efficient firms will survive, which will reduce productivity and competitiveness in the economy at a macro-economic level. In the case of investment aids, the risk of outcomes detrimental to economic efficiency is lower, but only if productivity criteria guaranteeing the productivity-enhancing effect of the investments are required.

Thus, whether we are talking about labour or capital, the post-crisis impact of using the anti-crisis toolbox may result in a decline in the productivity and competitiveness of the economy. In other words, some of the workers will be "overpaid" relative to their performance, businesses that are no longer viable and competitive under given economic conditions will survive, and more efficient businesses will not have access to adequate resources compared to their performance if the state gives money to businesses across-the-board and not subject to productivity and its increase.

The effect of changes in the global value chains

The outbreak of the pandemic in China triggered damage to global supply chains, as China is the leading power in world trade in goods. ${ }^{2}$ As the pandemic spread to the rest of the world, global supply-chain disruptions, slowdowns, and in some places, disintegrations were on the agenda. Supply chains cut through epidemiological constraints can only be partially rebuilt during the crisis, because although stagnation in production and slowdown in international trade shift the focus on local solutions, there are large disparities in capabilities and opportunities. At the same time, the security of supply has become a political issue and has led to a shift towards domestic solutions for many multinational companies - remember the Trump administration's paradigm to "relocate American multinational companies home", the which seems to be further justified by the crisis.

There is a danger that countries with policies similar to the United States will increasingly introduce cross-border restrictions on technology transfer, and this may lead to fragmented markets. The world may split into markets that adopt American/ European/Korean/Japanese technology and standards, and markets that adopt Chinese technology (suffice it to think of the anomalies observed with 5G). This, in turn, would adversely affect productivity, investment, and growth opportunities globally.

Internationally optimized production processes are thus moving towards localisation, with the consequent loss of efficiency and increase in cost. Globally, productivity, trade efficiency and optimisation are all declining. We are still at the beginning of the process and it is not known whether or not a substantial reorganisation will begin, but as long as the current de-globalisation lasts, development in the world economy will slow down as the potential for comparative advantage is reduced. This element has begun as an exogenous factor, but has become endogenous due to the role of global supply chains, although it retained its exogenous character through politics. 
Civic Review · Vol. 16, Special Issue, 2020

Slower growth target in China causes lower global growth prospects

It is expected that in the next few years the Chinese political leadership will focus on qualitative rather than quantitative growth (real GDP growth rate) compared to the previous decades (Fitch Solutions, 2020). It is likely that after the economic crisis triggered by the coronavirus, China will abandon its "growth at all costs" model and seek to reduce its recently growing indebtedness ${ }^{3}$ and high leverage. Based on the above, China's annual growth rate may fall to between 4 and 5.5 per cent over the next five years (Fitch Solutions, 2020). Considering that China accounts for about 17 per cent of global GDP and about 40 per cent of emerging countries' GDP, its slowdown will have a significant and direct impact on global growth. Moreover, China has contributed an average of 1.2 per centage points a year to world nominal GDP growth over the past decade. If, in the next decade, China's growth falls to an annual average of 5.5 per cent or even below, the world's global economic expansion will slow by at least 0.2 per centage points annually. In fact, this rate can even go above 0.2 per centage points because the above calculation is based only on the direct effect, not taking into account the negative impact of China's slowdown on growth in other countries (Fitch Solutions, 2020).

\section{Chances of slower recovery in the United States}

Due to its weight in world politics and in the global economy, recovery in the U.S. will have a significant impact on the development of the global economy and on the postcrisis growth opportunities of the rest of the world. Based on currently available data, the Congressional Budget Office (CBO) expects that reaching pre-crisis GDP levels in the U.S. may be a longer process, and might only happen after 2021.

Figure 1: Real GDP, Q4 2019 - Q4 2021 (on a Q4 2019 base, \%)

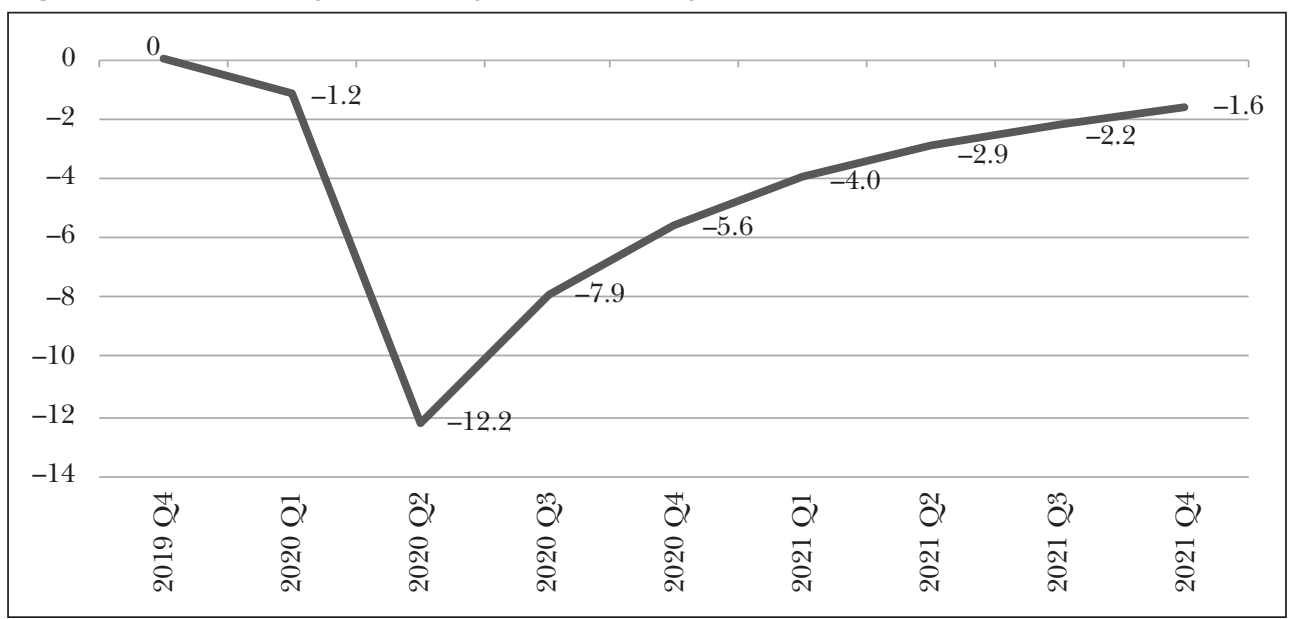

Source: Congressional Budget Office, $2020 \mathrm{~b}$ 
István Posgay, Gábor Regós, Diána Horváth, Dániel Molnár: On the Economic Impacts...

The reasons behind the slower recovery are outlined at several points (Congressional Budget Office, 2020a):

- Epidemiological restrictions are expected to be phased out only gradually and a new wave of pandemics cannot be ruled out, thus the CBO expects that restrictions will only be lifted completely at the end of 2021;

- Due to the timing of the economic support measures, the positive effects will appear only gradually and their impact will decrease in 2021;

- Experience from the last three economic expansion periods in the U.S. economy also points to a slow recovery path;

- Employment growth may start after Q3 2020, but those who have returned to work are likely to choose a more cautious spending strategy for some time, and so these households will make only a small contribution to expanding consumer demand.

Household savings in the European Union

The recovery of the European Union might be hampered by the higher savings rate of households, while so far they do not seem to be planning to spend the surplus, partly due to the risk of unemployment, and partly to fears of a second coronavirus wave (European Central Bank, 2020b; European Commission, 2020e, p. 190). The ECB also anticipates that households may set aside more than usual in the upcoming period, so the Central Bank forecasts that household consumption may start to increase in the second half of the year, but the pre-crisis level is only expected to be reached by 2022, and thus caution has a dampening effect on demand (European Central Bank, 2020a, p. 7).

\section{SUMMARY}

In the history of the economy, the 2020 coronavirus crisis is among those that were triggered by an external factor. In addition, the course of the recession, and the path of recovery will depend on the evolution of this external factor, namely the coronavirus pandemic. The downturn has opened considerable scope for the use of the monetary and fiscal anti-crisis measures applied since the 2008 crisis, and offers the opportunity to fine-tune them to the specificities of individual economies, which will have a significant impact on country-specific recovery. At the same time, a new element of the crisis is the loosening and occasional disintegration of international supply chains due to epidemiological restrictions, which may call into question the further continuation of the previously uninterrupted expansion in the trend of the global division of labour. The crisis is also a serious test of the former regime and institutional system of international economic cooperation and integration, and may bring significant changes in the world economy. 
Civic Review · Vol. 16, Special Issue, 2020

\section{Notes}

1 For a more comprehensive picture of the topic, see: International Monetary Fund, 2020; Nagy, 2020, pp. 16-21; European Commission, 2020a; 2020b; 2020c; 2020f; Leyen, 2020; France24, 2020.

2 According to 2018 data, China is the world's leading exporter of goods and the second largest importer, with shares of 12.8 and 10.8 per cent, respectively (World Trade Organisation, 2019, p. 100).

3 China's external debt, according to Trading Economics, nearly doubled between 2013 and 2019, reaching USD 2,057 billion, while its government debt-to-GDP ratio rose from 37 per cent to 50.5 per cent over the same period.

\section{REFERENGES}

Baldwin, R. and Weder di Mauro, B. (eds.) (2020): Mitigating the COVID Economic Crisis. Act Fast and Do Whatever It Takes. CEPR Press, London, https://voxeu.org/content/mitigating-covid-economic-crisisact-fast-and-do-whatever-it-takes (accessed 31 March 2020).

Bank of Japan (2020a): Establishment of „Principal Terms and Conditions of the Special Funds-Supplying Operations to Facilitate Corporate Financing Regarding the Novel Coronavirus (COVID-19)". Bank of Japan, 16 March, www.boj.or.jp/en/announcements/release_2020/rel200316f.pdf (accessed 17 March 2020).

Bank of Japan (2020b): Introduction of the Special Funds-Supplying Operations to Facilitate Corporate Financing Regarding the Novel Coronavirus (COVID-19). Bank of Japan, 16 March, www.boj.or.jp/en/ announcements/release_2020/rel200316e.pdf (accessed 17 March 2020).

Bank of Japan (2020c): Summary of Opinions at the Monetary Policy Meeting on March 16, 2020. Bank of Japan, 25 March, www.boj.or.jp/en/mopo/mpmsche_minu/opinion_2020/opi200316.pdf (accessed 25 March 2020).

Bartash, J. (2020): Trillions in Coronavirus Spending Could Explode Deficits to World War II Levels. MarketWatch, 1 April, www.marketwatch.com/story/trillions-in-coronavirus-spending-could-explode-deficitsto-world-war-two-levels-2020-03-31 (accessed 31 March 2020).

Bianchi, F.; Kung, H. and Morales, G. (2014): Growth, Slowdowns, and Recoveries. NBER Working Paper Series, Working Paper 20725.

Congressional Budget Office (2020a): Interim Economic Projections for 2020 and 2021. Congressional Budget Office, 19 May, www.cbo.gov/system/files/2020-05/56351-CBO-interim-projections.pdf (accessed 24 May 2020).

Congressional Budget Office (2020b): Data and Supplemental Information, Data Underlying Figures. www. cbo.gov/publication/56351.

Cox, J. (2020): 'Nothing is Out of the Question': What it Would Take for the FED to Start Buying Stocks. CNBC, 29 March, www.cnbc.com/2020/03/29/what-it-would-take-for-the-fed-to-start-buying-stocks-during-coronavirus-crisis.html (accessed 30 March 2020).

European Central Bank (2020a): Eurosystem Staff Macroeconomic Projections for the Euro Area. European Central Bank, June, www.ecb.europa.eu/pub/pdf/other/ecb.projections202006_ eurosystemstaff 7628a8cf43.en.pdf (accessed 5 June 2020).

European Central Bank (2020b): Pandemic Central Banking: the Monetary Stance, Market Stabilisation and Liquidity. European Central Bank, 19 May, www.ecb.europa.eu/press/key/date/2020/html/ecb. sp200519 e5203d3520.en.html (accessed 28 May 2020).

European Commission (2020a): Coronavirus Response. European Commission, COM(2020) 143 final, 2 April, https://ec.europa.eu/info/sites/info/files/using_every_available_euro.pdf (accessed 2 April 2020).

European Commission (2020b): Amendment to the Temporary Framework for State Aid Measures to Support the Economy in the Current COVID-19 Outbreak. European Commission, C(2020) 2215 final, 3 April, https:// ec.europa.eu/competition/state_aid/what_is_new/sa_covid19_1st_amendment_temporary_framework_en.pdf (accessed 3 April 2020). 


\section{István Posgay, Gábor Regős, Diána Horváth, Dániel Molnár: On the Economic Impacts...}

European Commission (2020c): Policy Measures Taken against the Spread and Impact of the Coronavirus. European Commission, 6 April, https://ec.europa.eu/info/sites/info/files/coronovirus-policy-measures-6-april_en_1.pdf (accessed 6 April 2020).

European Commission (2020d): The EU budget powering the recovery plan for Europe. European Commission, $\operatorname{COM}(2020) 442$ final, 27 May, https://ec.europa.eu/info/sites/info/files/about_the_european_commission/eu_budget/1_en_act_part1_v9.pdf (accessed 27 May 2020).

European Commission (2020e): European Economic Forecast, Spring 2020. European Commission, Institutional Paper 125, May, https://ec.europa.eu/info/sites/info/files/economy-finance/ip125_en.pdf (accessed 25 June 2020).

European Commission (2020f): State Aid: Commission Approves EUR140 Million Hungarian Scheme to Support Economy in Coronavirus Outbreak. European Commission, 8 April, https://ec.europa.eu/commission/ presscorner/detail/en/IP_20_629 (accessed 8 April 2020).

Federal Reserve System (2020a): The Beige Book. Summary of Commentary on Current Economic Conditions by Federal Reserve District. Federal Reserve System, www.federalreserve.gov/monetarypolicy/files/ BeigeBook_20200527.pdf (accessed 27 May 2020).

Federal Reserve System (2020b): Secondary Market Corporate Credit Facility. Federal Reserve System, 15 June, www.federalreserve.gov/newsevents/pressreleases/files/monetary20200615a1.pdf (accessed 15 June 2020).

Federal Reserve System (2020c): Federal Reserve Takes Additional Actions to Provide Up to USD2.3 Trillion in Loans to Support the Economy. Federal Reserve System, 9 April, www.federalreserve.gov/newsevents/pressreleases/monetary20200409a.htm (accessed 9 April 2020).

France24 (2020): EU Finance Ministers Reach Agreement on Coronavirus Rescue Deal. France24, 9 April, www.france24.com/en/20200409-eu-finance-ministers-reach-agreement-on-coronavirus-rescue-deal.

Fitch Solutions (2020): Six Drivers of Lower Trend Growth Over the Next Decade. Fitch Solutions, 13 May.

International Monetary Fund (2020): Policy Responses to COVID-19. International Monetary Fund, www.imf. org/en/Topics/imf-and-covid19/Policy-Responses-to-COVID-19\#F (accessed 9 April 2020).

Leyen, U. von der (2020): EC press conference by European Commission President Ursula von der Leyen, on SURE (EU short-time employment scheme), on the Emergency Support Instrument and on the Coronavirus Response Investment Initiative Plus. European Commission, https://audiovisual.ec.europa. eu/embed/index.html?ref=I-187941\&lg=undefined,

McKinsey \& Company (2020): COVID-19: Briefing Materials. Global Health and Crisis Response, 2020. McKinsey \& Company, 1 June.

Nagy, M. (2020): Háttérbeszélgetés a Monetáris Tanács 2020. márciusi kamatdöntése után [Background discussion after the March 2020 interest rate decision of the Monetary Council]. Hungarian National Bank, 24 March, www.mnb.hu/letoltes/nagy-marton-alelnok-ur-hatterbeszelgetes-stream-prezentacio-20200324. pdf.

Posgay, I.; Regôs, G.; Horváth, D. and Molnár, D. (2019): Chapters from Economic Theories on Hysteresis. Public Finance Quarterly, Vol. 64, No. 3, 414-432, https://doi.org/10.35551/PFQ_2019_3_.

Tan, H. (2020): The Coronavirus Outbreak is a 'Different Kind of Crisis,' says Nobel Laureate Joseph Stiglitz. CNBC, 17 March, www.cnbc.com/2020/03/17/joseph-stiglitz-coronavirus-outbreak-is-a-different-kind-of-crisis.html,

World Trade Organisation (2019): World Trade Statistical Review 2019. World Trade Organisation, www.wto. org/english/res_e/statis_e/wts2019_e/wts2019_e.pdf (accessed 25 May 2020) 